\title{
Environmental analysis along the supply chain of dark, milk and white chocolate: a life cycle comparison
}

\author{
F. R. Bianchi ${ }^{1} \cdot$ L. Moreschi ${ }^{1} \cdot$ M. Gallo ${ }^{1} \cdot$ E. Vesce ${ }^{2} \cdot$ A. Del Borghi ${ }^{1}$ (I) \\ Received: 21 February 2020 / Accepted: 25 August 2020 / Published online: 4 September 2020 \\ (C) The Author(s) 2020
}

\begin{abstract}
Purpose Environmental impact evaluation in the food sector is a key topic, due to both stricter legislations and higher consumer awareness towards sustainable choices. The case of chocolate is a remarkable example, owing to the increasing demand and the complex production process from cocoa beans to final bars. The present study aims at assessing the environmental impacts related to three chocolate types (dark, milk and white) through life cycle assessment (LCA) methodology.

Methods Consistent with food Product Category Rules (PCRs) and previous LCA literature, the study follows a cradle to grave approach. Among different raw material productions, it focuses above all on cocoa farming assuming three possible producer countries (i.e. Ghana, Ecuador and Indonesia), so that the influence of specific weather conditions and soil properties is underlined. Since the manufacturing step is supposed in the North Italian factory, different transport distances are also taken into account. Moreover, the work focuses on the possible use of several packaging materials and following disposal issues. In view of the open discussion about the most suitable functional unit in food sector, mass and energy amount approaches are compared.

Results and discussion Along chocolate supply chain, different phases are evaluated according to LCA methodology. Among analyzed producer countries: Indonesia monoculture case results to be the most impacting situation, due to an intensive use of agrochemicals; pesticides give a wide contribution in Ecuador, whereas Ghana is penalized by the highest water consumption. The transport of beans to manufacturing plant influences mostly the GWP, owing to long travelled distances. Considering the whole production process, cocoa derivatives and milk powder are the main contributors to every impact category. From packaging point of view, the best solution is the use of a single polypropylene layer. A sensitivity analysis is performed to check the validity of different allocation procedures: both mass and energy content allocations lead to similar results.

Conclusions Through LCA methodology, the life cycle of dark, milk and white chocolate is compared. The study assesses different potential environmental impacts, assuming mass and energy content as possible functional units and references for allocation procedures. For all combinations of functional units and allocation rules, dark chocolate globally presents the best environmental performance, whereas the other two types have similar environmental impacts.
\end{abstract}

Keywords Chocolate $\cdot$ Food processing $\cdot$ Life cycle assessment $\cdot$ Sensitivity analysis

Responsible editor: Carlo Ingrao

Electronic supplementary material The online version of this article (https://doi.org/10.1007/s11367-020-01817-6) contains supplementary material, which is available to authorized users.

A. Del Borghi

adriana.delborghi@unige.it

F. R. Bianchi

fiammettarita.bianchi@edu.unige.it

L. Moreschi

luca.moreschi@edu.unige.it

M. Gallo

michela.gallo@unige.it
E. Vesce

enrica.vesce@unito.it

1 Department of Civil, Chemical and Environmental Engineering (DICCA), University of Genoa, Via all'Opera Pia 15, 16145 Genoa, Italy

2 Department of Management, University of Turin, 10124 Turin, Italy 


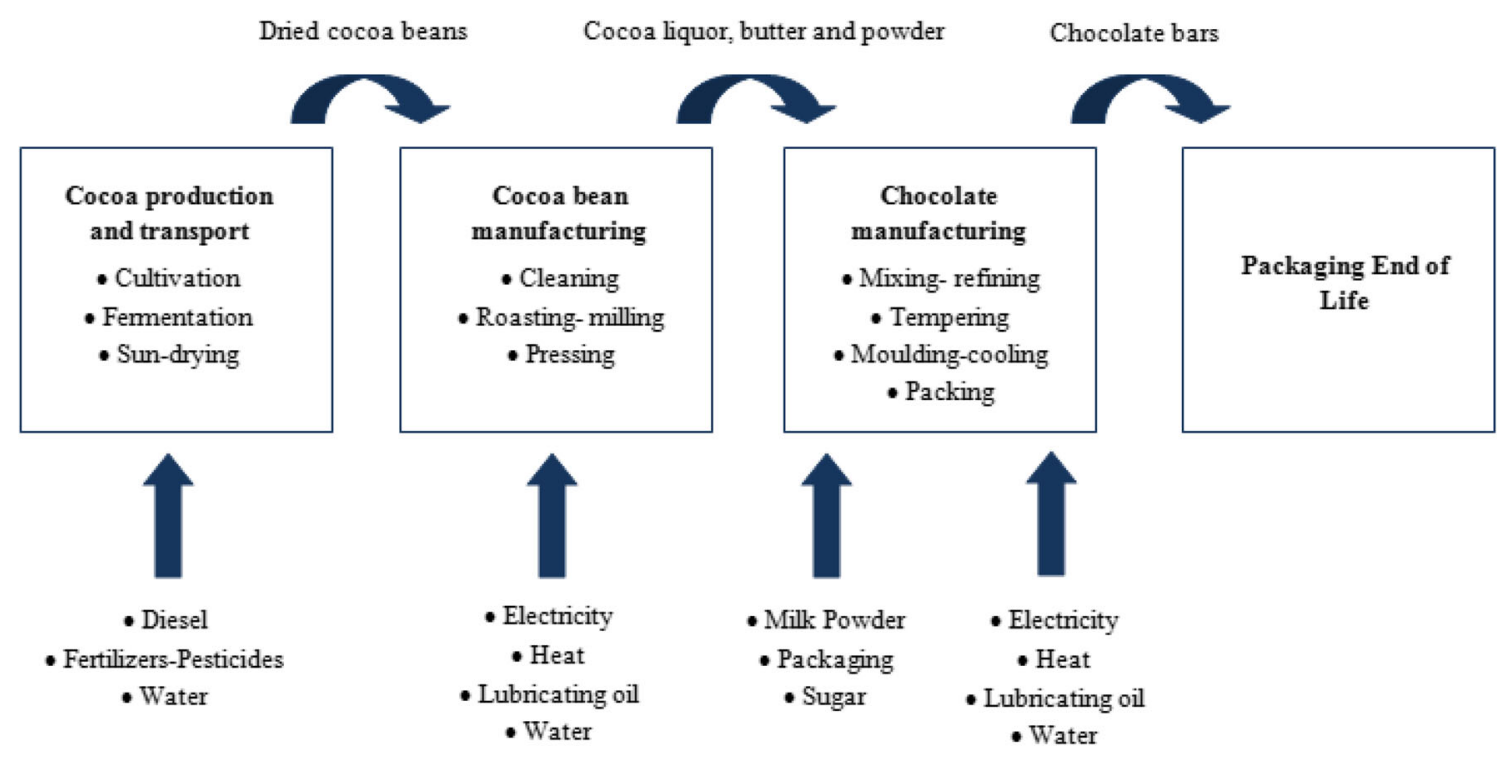

Fig. 1 System boundaries

\section{Introduction}

Nowadays, the environmental sustainability is emerging as key-point in the agri-food sector because of its remarkable impacts. For instance, food sector causes more than $25 \%$ of global greenhouse gas (GHG) emissions (Solazzo et al. 2016). It needs high water consumption and it uses about half of icefree land area on the Earth for cropland and pasture, which provokes deforestation (Barona et al. 2010). Moreover, alimentary brands focus more and more on these issues, since consumers begin to be conscious of the global pollution and to consider not only the product quality but also its potential damages to the environment. Life cycle assessment (LCA) currently is the best standardized methodology to analyze the environmental aspects since it enables to highlight and study correlations between production systems and natural resource depletion, i.e. Water-Energy-Food Nexus (Del Borghi et al. 2020). Several studies aimed at evaluating environmental consequences due to food production chain: fruit and grain farm (Ingrao et al. 2015; Tricase et al. 2018), processed foods (Canellada et al. 2018; Del Borghi et al. 2014; Ingrao et al. 2018), seafood and meat (Hospido et al. 2006; López-Andrés et al. 2018). In this context, packaging is also considered to have an effective impact estimation (Del Borghi et al. 2018; Strazza et al. 2016). However, LCA still seeks to become a tool for combined analyses of economic value and eco-burden, creating new sustainable business models in view of the transition towards a circular economy (Scheepens et al. 2016).

Environmental concerns are critical in chocolate supply chain. Cocoa is only produced in tropical zones of America, Africa and Asia growing in specific humidity conditions, whereas transformation processes and principal markets are usually in Europe and North America. Indeed, there is a remarkable contrast between cocoa production and demand in different areas: for instance, Europe is the major consumer with an average annual request of 1812 ktons, followed by the USA characterized by a national consumption of 775 ktons, while only 146 ktons are eaten in Africa, which is the first worldwide farmer with 3185 ktons of produced cocoa (García-Herrero et al. 2019). Therefore, raw materials are transported for long distances. The manufacturing is quite complex because several co-products can be derived from cocoa beans and other ingredients are added to obtain the final product. The effects due to cocoa life cycle cannot be neglected anymore, in view of the increasing chocolate
Table 1 Assumed percentages of ingredients in dark, milk and white chocolate observing normative limits

\begin{tabular}{|c|c|c|c|c|c|c|}
\hline \multirow[t]{2}{*}{ Ingredients } & \multicolumn{2}{|l|}{ Dark } & \multicolumn{2}{|l|}{ Milk } & \multicolumn{2}{|l|}{ White } \\
\hline & Assumption & Normative & Assumption & Normative & Assumption & Normative \\
\hline Cocoa butter & $28 \%$ & $\geq 28 \%$ & $15 \%$ & - & $35 \%$ & $\geq 20 \%$ \\
\hline $\begin{array}{l}\text { Cocoa liquor } \\
\text { Cocoa powder }\end{array}$ & $\begin{array}{l}42 \% \\
16 \%\end{array}$ & $\geq 45 \%$ & $\begin{array}{l}25 \% \\
0 \%\end{array}$ & $\geq 25 \%$ & $\begin{array}{l}0 \% \\
0 \%\end{array}$ & - \\
\hline Milk powder & $0 \%$ & - & $20 \%$ & $\geq 14 \%$ & $20 \%$ & $\geq 14 \%$ \\
\hline Sugar & $14 \%$ & - & $40 \%$ & $\leq 55 \%$ & $45 \%$ & $\leq 55 \%$ \\
\hline
\end{tabular}


Table 2 Input data for the farm of $1 \mathrm{~kg}$ of dried cocoa beans (Ecuador EC, Ghana GH, Indonesia monoculture system IDm, Indonesia agroforestry system IDa)

\begin{tabular}{llllll}
\hline Input & EC & GH & IDm & IDa & Unit \\
\hline Fertilizer N & 0.058 & - & - & - & $\mathrm{kg}$ \\
Fertilizer P & 0.175 & 0.125 & - & - & $\mathrm{kg}$ \\
Fertilizer K & 0.058 & 0.050 & - & - & $\mathrm{kg}$ \\
Organic fertilizer & - & - & 0.021 & 0.015 & $\mathrm{~kg}$ \\
Urea, as N & - & - & 0.222 & 0.117 & $\mathrm{~kg}$ \\
KCl, as K & - & - & 0.164 & 0.047 & $\mathrm{~kg}$ \\
SP-36, as P & - & - & 0.076 & 0.032 & $\mathrm{~kg}$ \\
TSP, as P & - & - & 0.022 & 0.014 & $\mathrm{~kg}$ \\
Pesticide & 0.040 & 0.016 & 0.032 & 0.019 & $\mathrm{~kg}$ \\
Diesel & - & - & 0.012 & 0.011 & $\mathrm{~kg}$ \\
Water & - & $2,980.306$ & 7.000 & 4.644 & $\mathrm{~kg}$ \\
\hline
\end{tabular}

consumption. According to the Food and Agriculture Organization (FAO), the global demand of this food and its derivatives has been risen about $91 \%$ in the last 20 years (FAO 2017). If different types are considered, the dark chocolate is expected to have a trend of $8.5 \%$ compound annual growth rate (CAGR) (CBI 2019), followed by white one 6.5\% CAGR (Persistence Market Research 2018) and milk one 6.2\% CAGR (Transparency Market Research 2018) during the assessment period 2017-2026. The increasing demand has provoked cocoa farming intensification by expanding into new lands, including forest ones, or by using more fertilizers and pesticides to improve the yield.

Nowadays, there are no specific environmental certifications based on quantitative assessment like the Environmental Product Declaration (EPD) by the International EPD® System or the related Product Category Rules (PCRs) (ISO 2006a) for the chocolate sector. However, several studies propose the life cycle assessment of cocoa derivatives. The LCA is a standardized methodological tool that enables the assessment of the main environmental aspects associated to a specific product "from the cradle to the grave", through the evaluation of different input and output flows and their correlated potential environmental impacts according to ISO 14040 (ISO 2006b) and ISO 14044 (ISO 2006c). In food
Table 4 Transport distances (departure ports: Guayaquil for Ecuador EC, Tema for Ghana GH, Makassar for Indonesia ID)

\begin{tabular}{lllll}
\hline Transport & EC & GH & ID & Unit \\
\hline From cocoa field to departure port & 230 & 280 & 260 & $\mathrm{~km}$ \\
From departure port to Genoa port & 11,200 & 6920 & 13,790 & $\mathrm{~km}$ \\
From Genoa port to factory & 100 & 100 & 100 & $\mathrm{~km}$ \\
Total distance & 11,530 & 7300 & 14,150 & $\mathrm{~km}$ \\
\hline
\end{tabular}

fields, there are a lot of discussions concerning LCA approaches to be followed (McAuliffe et al. 2020). One of the main issues is the definition of proper functional units, which should provide a measurement of specific peculiarity of every product so as to enable the comparison among different systems. One kilogram of product is usually assumed (Roy et al. 2009), still this does not efficaciously represent the actual quantitative consumption of different food. A more realistic view is provided focusing on the nutritional value and the caloric intake. Here, the evaluation of potential environmental impacts is paired with health benefits. Some examples of this innovative perspective are the use of grams of proteins (Sonesson et al. 2017), energy amount (Nemecek et al. 2016), nutritional quality index or fullness factor (Chapa et al. 2020) as LCA functional unit.

In the case of chocolate, the common approach proposes the use of mass unit as reference for different inputs and outputs of the system. Its life cycle is usually divided into cocoa farming, transport, manufacturing, sale and end of life. There are some authors that analyze specifically the raw material cultivation in different areas: Ghana (Ntiamoah and Afrane 2008), Colombia (Ortiz et al. 2014) or Indonesia (Utomo et al. 2016). Others also consider the manufacturing (Büsser and Jungbluth 2009; Pérez Neira 2016), or the transport and the transformation neglecting the cultivation step (Vesce et al. 2016). Only packaging material can be also studied specifically (Allione et al. 2011), whereas few works take into account the whole life cycle (Miah et al. 2018; Recanati et al. 2018; Konstantas et al. 2018). Still, in all these cases, they focus on dark chocolate or chocolate derivatives, such as chocolate biscuits and wafers or moulded chocolate. So, the obtained results are not specific for chocolate life cycle, but
Table 3 Emission coefficients for the production of $1 \mathrm{~kg}$ of dried cocoa beans (Ecuador EC, Ghana $\mathrm{GH}$, Indonesia monoculture system IDm, Indonesia agroforestry system IDa)

\begin{tabular}{llllll}
\hline & & EC & GH & IDm & IDa \\
\hline Emissions to air & Ammonia & 0.0022 & 0.0000 & 0.0540 & 0.0283 \\
& Dinitrogen monoxide & 0.0006 & 0.0000 & 0.0035 & 0.0018 \\
& Nitrogen monoxide & 0.0004 & 0.0000 & 0.0016 & 0.0008 \\
Emissions to water & Nitrate & 0.0175 & 0.0000 & 0.0667 & 0.0350 \\
& Phosphate & 0.0027 & 0.0018 & 0.0016 & 0.0004 \\
\hline
\end{tabular}


Table 5 Input data for trigeneration process

\begin{tabular}{|c|c|c|}
\hline & Value & Unit \\
\hline \multicolumn{3}{|l|}{ Input } \\
\hline Heat & 1.188 & $\mathrm{kWh}$ \\
\hline \multicolumn{3}{|l|}{ Output } \\
\hline Electricity (trigeneration) & 0.500 & $\mathrm{kWh}$ \\
\hline Heat (trigeneration) & 0.354 & $\mathrm{kWh}$ \\
\hline Cooling (trigeneration) & 0.146 & $\mathrm{kWh}$ \\
\hline
\end{tabular}

they are influenced by a lot of other factors. Moreover, the milk and white types are rarely analyzed.

Here, the present study aims at providing a more complete analysis through LCA methodology, based on a "cradle to grave" approach. Three common chocolate types (dark, milk and white, each one with a specific recipe) are evaluated and compared in order to detect which ingredients provoke the major potential environmental impacts. Since cocoa origin has more and more influenced consumer choice in last years (Torres-Moreno et al. 2012), a more detailed analysis of farming step is performed. The comparison among different producer countries highlights the relevance of this phase and how the results vary in function of the considered cocoa supply chain. Another relevant factor is due to packaging, so three different commercial solutions are compared. Firstly, the study follows the common literature approach of $1 \mathrm{~kg}$ of product as functional unit, consequently all the allocations are performed in terms of mass. Then, in view of chocolate calorie intake (Cooper et al. 2008), the analysis is also carried out considering $1 \mathrm{kcal}$ as functional unit, to highlight if the previous identified trends are confirmed by this second approach.
Table 7 Input data of different packaging case studies for $1 \mathrm{~kg}$ of chocolate

\begin{tabular}{lllll}
\hline Packaging & PP & Cardboard & Paper & Unit \\
\hline Polypropylene & 0.020 & - & - & $\mathrm{kg}$ \\
Aluminium foil & - & 0.018 & 0.018 & $\mathrm{~kg}$ \\
Fibre-based layer & - & 0.118 & 0.024 & $\mathrm{~kg}$ \\
\hline
\end{tabular}

\section{Methods and data}

The environmental potential impacts deriving from chocolate production are assessed according to LCA methodology as defined by ISO 14040-44 (ISO 2006b, c). Since no specific PCR is furnished by the International EPD® System for this product category, suggested approach for generic food products is followed (IES 2019).

\subsection{Goal and scope of the study}

The present study aims at detecting the potential environmental impacts due to the life cycle of three chocolate types: dark, milk and white ones. Two different approaches are followed: firstly, $1 \mathrm{~kg}$ of chocolate is assumed as functional unit according to the guidelines of the PCR Basic Module for food products (IES 2019); then, $1 \mathrm{kcal}$ is defined as functional unit for a further comparison of the analyzed products. The study considers the life cycle "from cradle to grave", dividing it into raw material production (i.e. cocoa, milk powder, sugar and final product packaging), cocoa transport, chocolate manufacturing and packaging waste management (Fig. 1). The packaging material for cocoa bean transport, usually jute sacks, is excluded. The retail and storage steps are neglected since they
Table 6 Input data in chocolate transforming factory (outputs derived from Table 1)

\begin{tabular}{llll}
\hline & Cocoa manufacturing & Chocolate refining & Unit \\
\hline Input & & & \\
Electricity (trigeneration) & 0.18 & 0.48 & $\mathrm{kWh}$ \\
Heat (trigeneration) & 0.13 & 0.34 & $\mathrm{kWh}$ \\
Cooling (trigeneration) & 0.05 & 0.14 & $\mathrm{kWh}$ \\
Other heat (natural gas) & 0.635 & 0.388 & $\mathrm{MJ}$ \\
Lubricating oil & 17.6 & 46.2 & $\mathrm{Mg}$ \\
Water & 0.9 & 1.7 & $\mathrm{~kg}$ \\
Cocoa beans & 0.530 & - & $\mathrm{kg}$ \\
Output & & & $\mathrm{kg}$ \\
Cocoa liquor & 0.098 & - & $\mathrm{kg}$ \\
Cocoa butter & 0.202 & - & $\mathrm{kg}$ \\
Cocoa powder & 0.160 & - & $\mathrm{kg}$ \\
Chocolate & - & 1 & \\
\hline
\end{tabular}


Table 8 End-of-life scenarios for packaging materials

\begin{tabular}{lllll}
\hline Packaging & Sanitary landfill & Incineration & Recycling & Source \\
\hline Polypropylene & $12.5 \%$ & $43 \%$ & $44.5 \%$ & Corepla (2019) \\
Aluminium foil & $13.4 \%$ & $6.4 \%$ & $80.2 \%$ & CiAl (2019) \\
Fibre-based layer & $11.2 \%$ & $7.7 \%$ & $81.1 \%$ & Comieco (2019) \\
\hline
\end{tabular}

equally apply to three chocolate types and do not affect the comparison.

The study is performed using the simulation software SimaPro 9 and the database Ecoinventv.3.5 (Wernet et al. 2016).

According to the PCR Basic Module for food products (IES 2019), the following indicators for environmental impacts and for resource use are considered: Acidification potential (AP) according to CML 2001 non-baseline-January 2016 (University of Leiden 2016); eutrophication potential (EP), global warming potential (GWP), abiotic depletion elements (ADP, el), abiotic depletion - fossil fuels (ADP, ff) according to CML 2001 baseline-January 2016 (University of Leiden 2016); photochemical oxidant creation potential (POCP) according to ReCiPe 2008 (Goedkoop et al. 2009); net water use and cumulative energy demand (CED).

\subsection{Life cycle inventory}

In the inventory analysis, data about dark, milk and white chocolate supply chain are collected by secondary and tertiary sources: in particular, numerical data for cocoa co-products and milk powder production and for chocolate manufacturing are referred to existing recent literature, whereas data for the production of sugar and other auxiliary materials (e.g. fertilizers, pesticides) are retrieved from specific processes available in Ecoinvent v. 3.5 (Wernet et al. 2016). Then, all phases involved in the supply chain are modelled through SimaPro 9 software. The percentage of different ingredients is defined according to All. I, d.lgs. n. 178/2003 (European Directive 2000/36/CE) (ADICONSUM 2003). The lecithin, used as an emulsifier, is neglected due to low present amount. Table 1 reports proposed chocolate composition, with the reference ranges in European legislation.

In the following paragraphs, inventory data of the main steps of chocolate supply chain are presented in more details.

\subsubsection{Raw material production and transport}

The basic ingredient of chocolate is cocoa, which is cultivated in tropical regions. In the present LCA, three countries are taken into account as cocoa producers: Ecuador, Ghana and Indonesia. In a commercial stand, there is usually a density of 1100-1200 trees/ha. Since the yield is low in comparison with other tropical cultivars - for instance 150-450 kg cocoa/ha (ICCO 2020) instead of 500-1000 kg coffee/ha (Gebreselassie et al. 2017) and 30,000-50,000 kg banana/ha (Nayak et al. 2019) — the land occupation is very high. Moreover, cacao trees are not disease-resistant, so an intensive use of fertilizers and pesticides is required to increase the production. As shown in Table 2, input data for three considered areas change because of the climate, the humidity and the soil characteristics. In Ecuador case study, a traditional process, characterized by low fertilizer use per hectare and poor cocoa yield, is represented (Pérez Neira 2016). A traditional approach is also modelled for Ghana (Recanati et al. 2018),

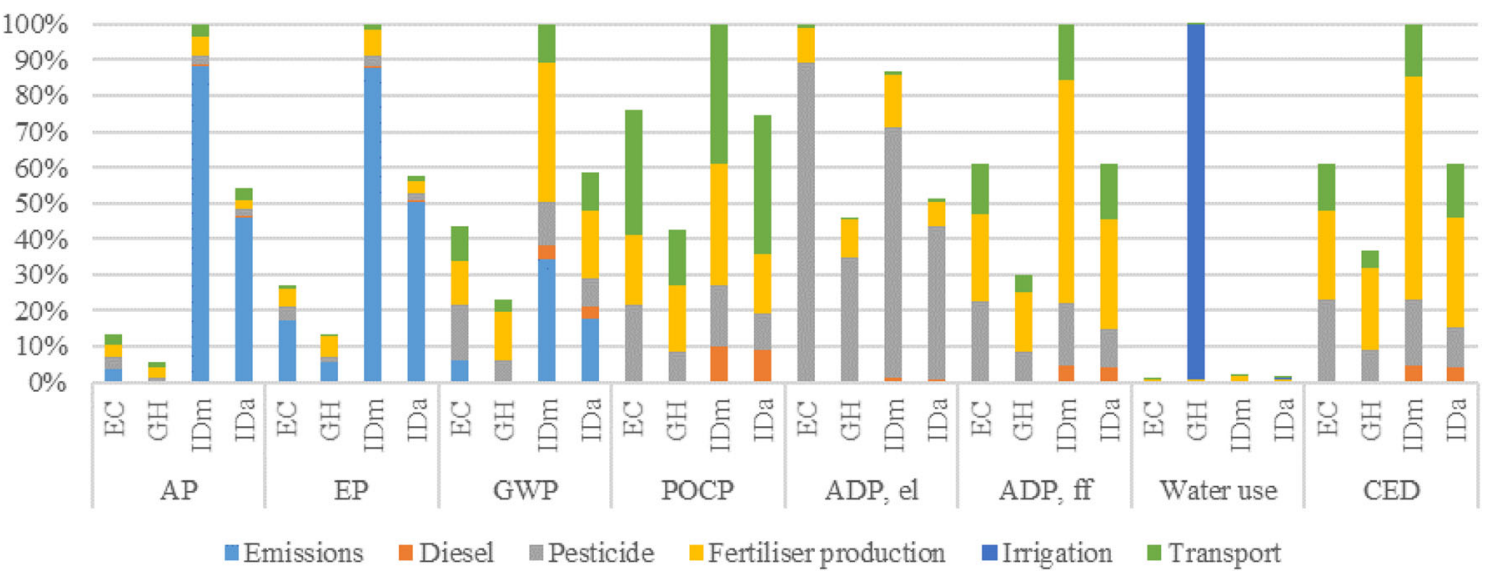

Fig. 2 Environmental impacts due to farm and transport of dried cocoa beans (Ecuador EC, Ghana GH, Indonesia monoculture system IDm, Indonesia agroforestry system IDa) 
Fig. 3 AP impacts of $1 \mathrm{~kg}$ dark, milk and white chocolate according to mass allocation (Ecuador EC, Ghana GH, Indonesia monoculture system IDm, Indonesia agroforestry system IDa)

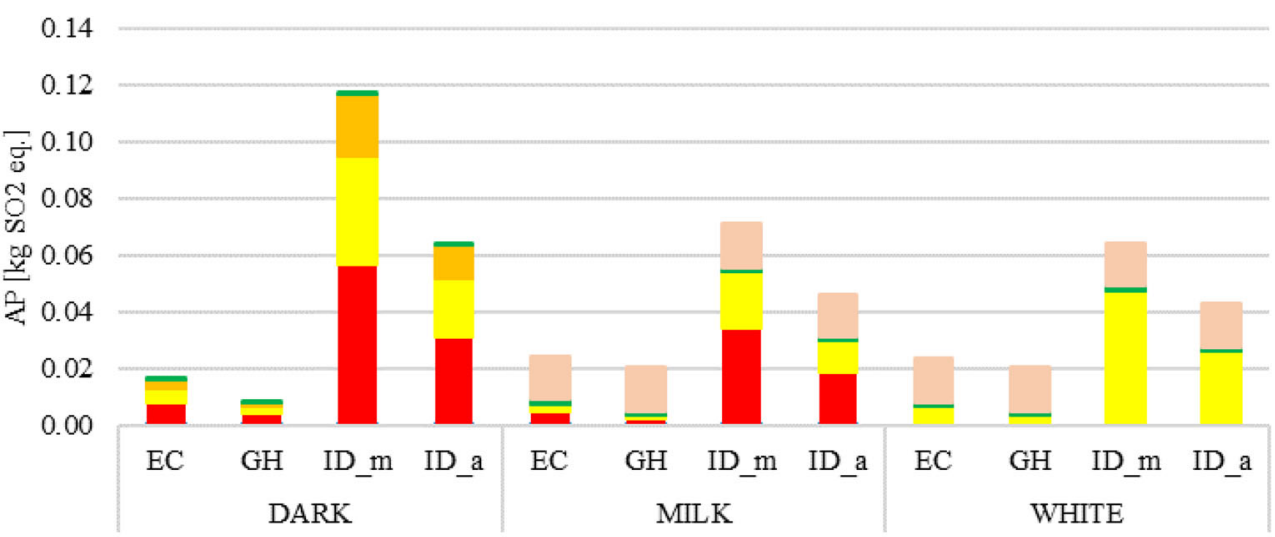

Energy and oil $\square$ Water $\square$ Cocoa liquor $\quad$ Cocoa butter $\square$ Cocoa powder $\square$ Sugar $\square$ Milk powder while both traditional monoculture and agroforestry systems are studied for Indonesia (Utomo et al. 2016). For the latter country, data are referred to cocoa pod: therefore, the request of $16 \mathrm{~kg}$ of cocoa pods to obtain $1 \mathrm{~kg}$ of cocoa dried beans is assumed. The emissions deriving from the application of fertilizers are evaluated according to the existing literature (Bouwman et al. 2002; EMEP/CORINAIR 2002; IPCC 2006) and are reported in Table 3 . The emissions deriving from the use of diesel are instead evaluated according to specific Ecoinvent database processes.

When cocoa fruits are harvested manually, the external husks are eliminated and usually left on fields as fertilizers. Then, there is the cocoa bean fermentation, which is a spontaneous process to improve aromas and reduce liquid content. The sun-drying for water and acidity elimination follows. Both phases do not request any specific energetic inputs (in few cases an artificial drying with hot air is used).

The dried cocoa beans are transported from tropical zones, where they are grown, to factories in North America and Europe. The itinerary is divided into three parts:

- A first route from the cultivation site to the departure port by a lorry 3.5-7.5 t EURO3
- A trans-oceanic ship transport to the chocolate producer country

- The final step from the Italian harbour to the transformation factory by a lorry 16-32 t EURO5

All transportation data are presented in Table 4. The first step is estimated from literature (Pérez Neira 2016; Ntiamoah and Afrane 2008; Recanati et al. 2018), whereas the others are calculated considering the distance between the specific port and the manufacturing factory located in Piedmont, Italy.

The input data of other ingredients are calculated considering the needed different amounts for every specific chocolate type (according to Table 1).

\subsubsection{Chocolate manufacturing}

The transformation step requests several unit operations. After the cleaning and the selection, cocoa dried beans are roasted at $120-180{ }^{\circ} \mathrm{C}$ to develop aromas and to sterilize the product. Then, the milling transforms beans into cocoa liquor, which is partly fed at the pressing operation to divide the cocoa fat butter from the cocoa dried cake (its further grinding produces cocoa powder). After addition of all ingredients, the mixture is
Fig. 4 EP impacts of $1 \mathrm{~kg}$ dark, milk and white chocolate according to mass allocation (Ecuador EC, Ghana GH, Indonesia monoculture system IDm, Indonesia agroforestry system IDa)

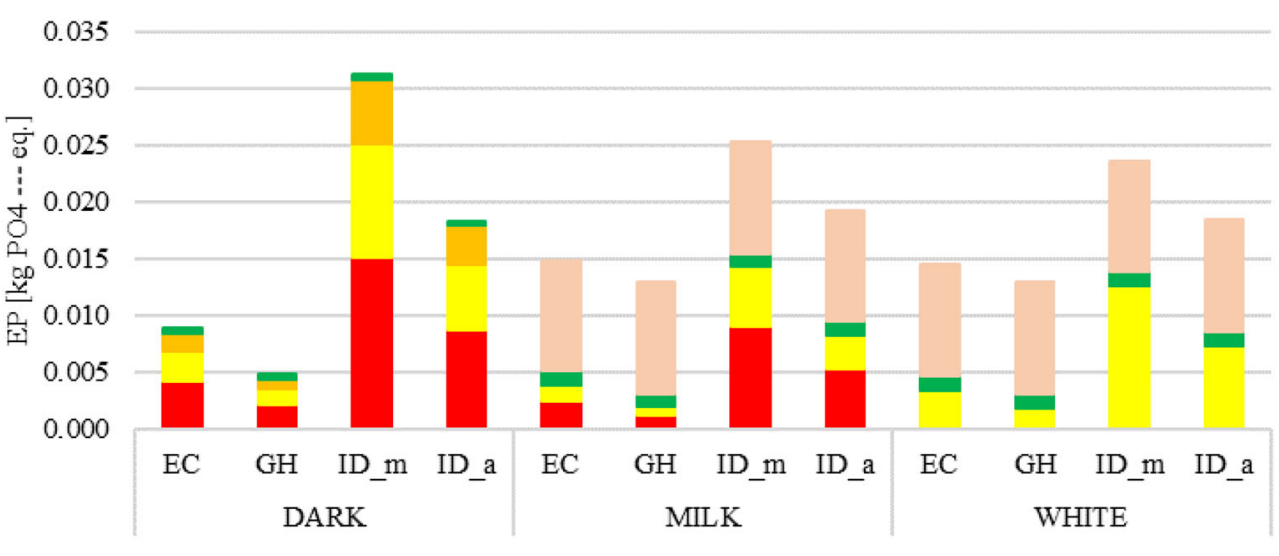

Energy and oil $\square$ Water $\square$ Cocoa liquor Cocoa butter $\square$ Cocoa powder $\square$ Sugar Milk powder 
Fig. 5 GWP impacts of $1 \mathrm{~kg}$ dark, milk and white chocolate according to mass allocation (Ecuador EC, Ghana GH, Indonesia monoculture system IDm, Indonesia agroforestry system IDa)

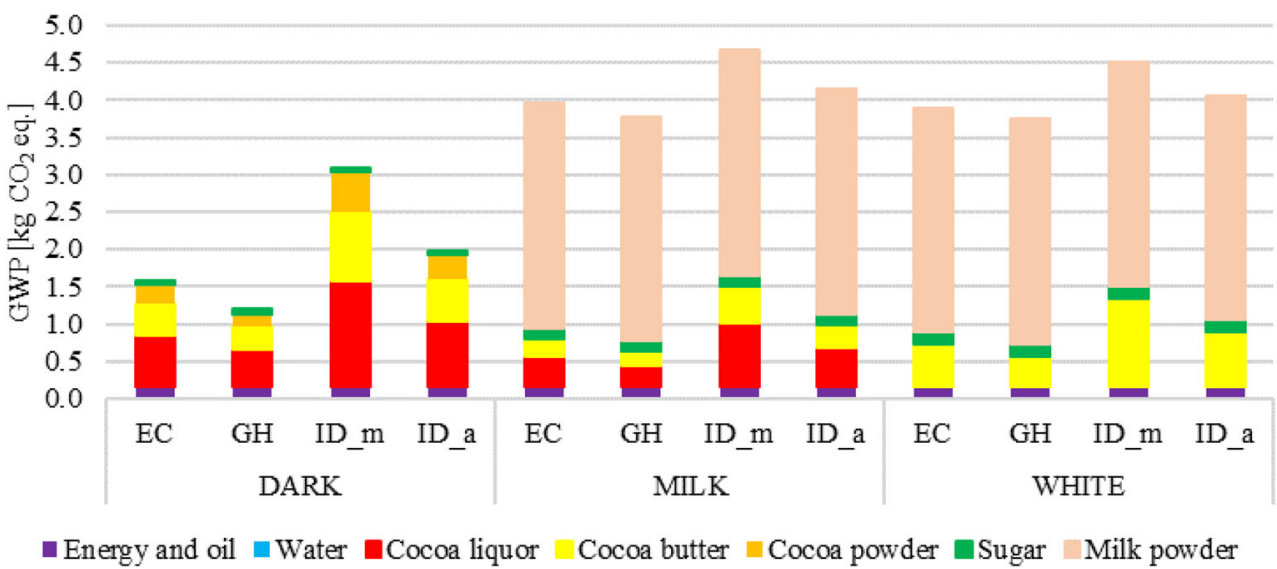

blended through the refining and the conching units at 50-80 ${ }^{\circ} \mathrm{C}$. The obtained liquid chocolate is tempered in order to cool it down slowly and then it is poured into specific moulds before wrapping into packaging. So, whereas water use is low, the whole process needs high amount of energy in the form of electricity, heat and cooling. A valuable opportunity is the addition of a trigeneration system to optimize process design, as described in Table 5 (Reverberi et al. 2011). As reported in Table 6 , both manufacturing phases are modelled according to Recanati et al. (2018): it is assumed that the requested heat is provided by trigeneration and partially by supplementary natural gas, whereas electricity and cooling are derived only by the trigeneration process. Input data for the chocolate manufacturing are firstly mass allocated among different co-products - cocoa liquor $(21.3 \%)$, cocoa butter $(43.9 \%)$ and cocoa powder $(34.8 \%)$ - and then through energy content approach (MP\&F 2020).

\subsubsection{Packaging materials and end of life}

On market, chocolate bars are wrapped by several possible materials, considering the requested properties to guarantee intact aroma. As shown in Table 7, four different packaging solutions are evaluated. An option is a sole polypropylene (PP) packaging; another is an aluminium film packed with a fibre-based material: respectively a cardboard (Recanati et al. 2018) and a kraft paper.

The end of life of the different packaging materials is defined according to the Italian scenario in 2018, as reported in Table 8.

\section{Results and discussion}

The LCA provides practical key measures which allow an easy comparison among different possible conditions. Process hotspots are detected, so effective changes can be introduced for system optimization. In view of that, firstly, impacts due to cocoa farm and transport are presented to underline critical points of the main raw material in the chocolate supply chain. Then, the whole production process is considered to compare three chocolate types, owing to different requested ingredients. Finally, the production and the end-oflife treatment of packaging materials are also taken into account as addition causes common for every analyzed case.
Fig. 6 POCP impacts of $1 \mathrm{~kg}$ dark, milk and white chocolate according to mass allocation (Ecuador EC, Ghana GH, Indonesia monoculture system IDm, Indonesia agroforestry system IDa)

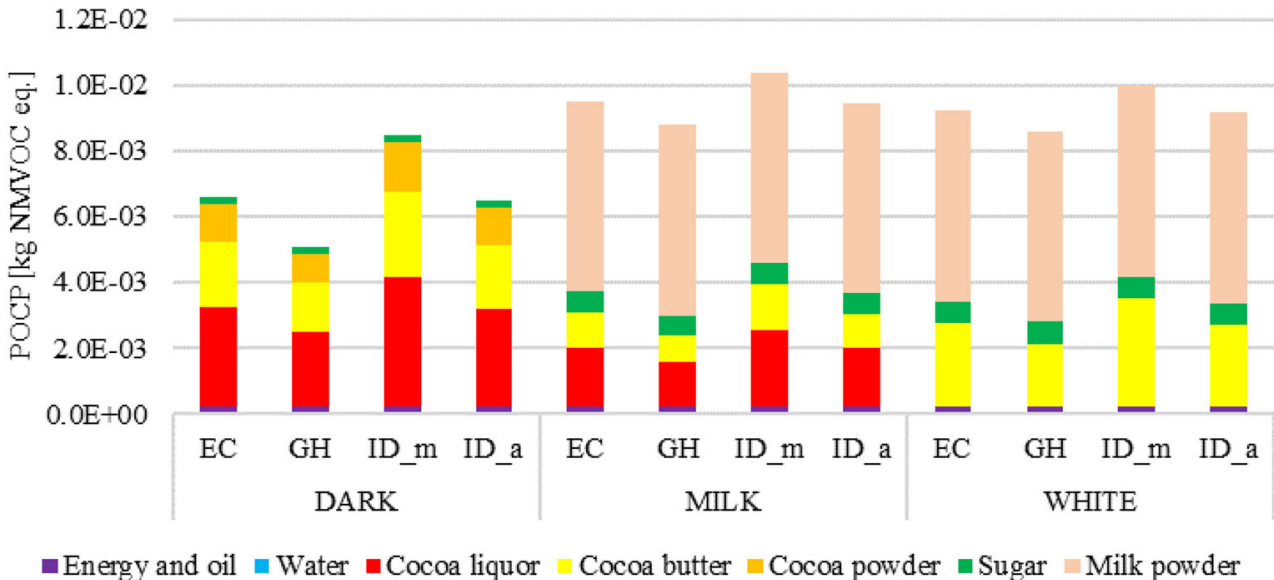


Fig. 7 ADP, elements impacts of $1 \mathrm{~kg}$ dark, milk and white chocolate according to mass allocation (Ecuador EC, Ghana $\mathrm{GH}$, Indonesia monoculture system IDm, Indonesia agroforestry system IDa)

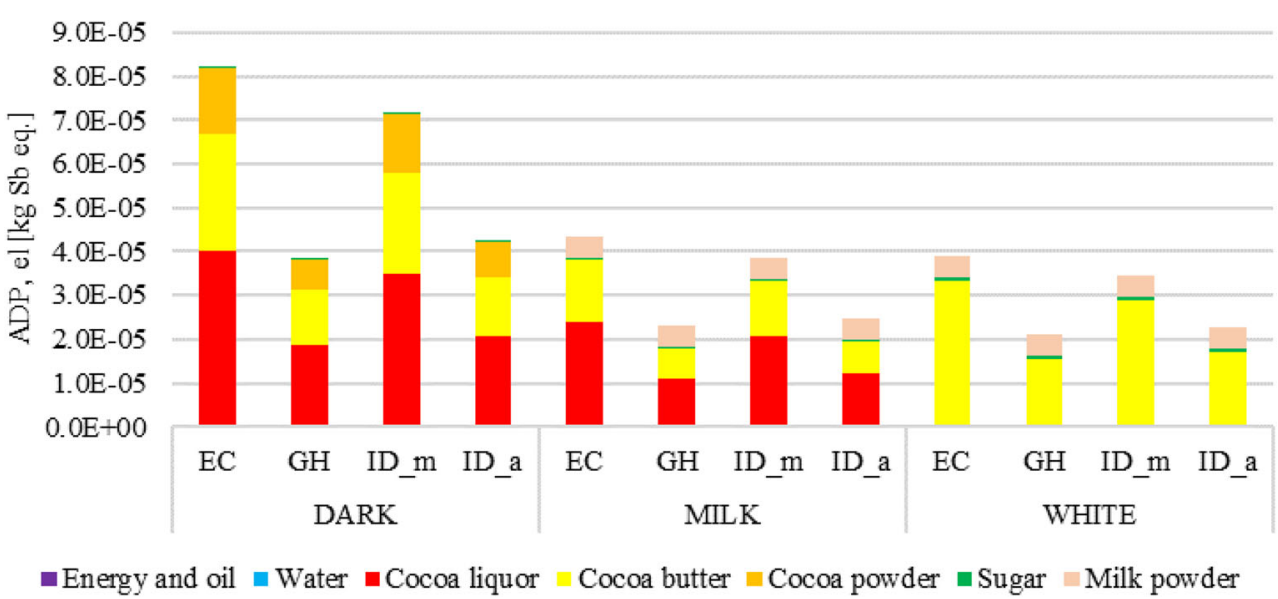

\subsection{Cocoa farm and transport}

Cocoa farm is characterized by a relevantly high emission impact, in relation to other permanent fruit cultivars: low yield per hectare is the main reason in this regard. Indeed, the usable product is limited considering the elimination of husks, the weight lost during fermentation and sun-drying. Moreover, the increased demand in the last period has forced the production optimization through an intensive use of chemical substances. For every analyzed case, synthesis and usage of fertilizers are the main sources of environmental impacts. As Fig. 2 shows, Indonesia monoculture case represents the worst condition. The emission of NO into air and those of nitrate and phosphate into water, both due to $\mathrm{N}$ - and P-based component application, respectively contribute to more than $85 \%$ of AP $(88.1 \%)$ and EP $(88.5 \%)$. The direct and indirect emissions of $\mathrm{N}_{2} \mathrm{O}$ also cause $34.3 \%$ of the total GWP, whereas the fertilizer production adds another $38.9 \%$ to GWP and consumes $62.2 \%$ of the total energy (CED) requested by the cultivation phase. In the Ecuador case study, pesticides have a higher contribution: for instance, $23.3 \%$ of AP, $14.1 \%$ of EP and $35.9 \%$ of GWP in comparison with $2.5 \%$ of AP, $3 \%$ of EP and $12.3 \%$ of GWP in
Indonesia monoculture system. Except for water consumption, Ghana shows the best performance in all the impact categories owing to the application of $\mathrm{N}$-free fertilizers and the absence of diesel consumption in agricultural machinery. A possible optimization is the substitution of the agrochemicals with organic products. Since the cocoa production stage creates a large amount of solid waste due to husks (about the $67 \%$ of the fresh pod weight), these may become organic fertilizers. Moreover, cocoa residue could be also used for bioenergy production (Kamp and Østergård 2016).

As Fig. 2 shows, pollution due to the transport step is influenced by travelled distances, so Ghana scenario results to be the best solution. Among all the case studies, GWP, POCP and CED are the categories mainly affected by the transportation phase: from $10.8 \%$ for Indonesia monoculture system to $22.3 \%$ for Ecuador in the case of GWP; from $36.7 \%$ for Ghana to $52.3 \%$ for Indonesia agroforestry system in the case of POCP; and from $12.9 \%$ in Ghana to $24.1 \%$ in Indonesia agroforestry system in the case of CED.

As far as Abiotic Depletion is concerned, pesticide production results the most impacting process (above 75\%) in terms of ADP,
Fig. 8 ADP, fossil fuels impacts of $1 \mathrm{~kg}$ dark, milk and white chocolate according to mass allocation (Ecuador EC, Ghana $\mathrm{GH}$, Indonesia monoculture system IDm, Indonesia agroforestry system IDa)

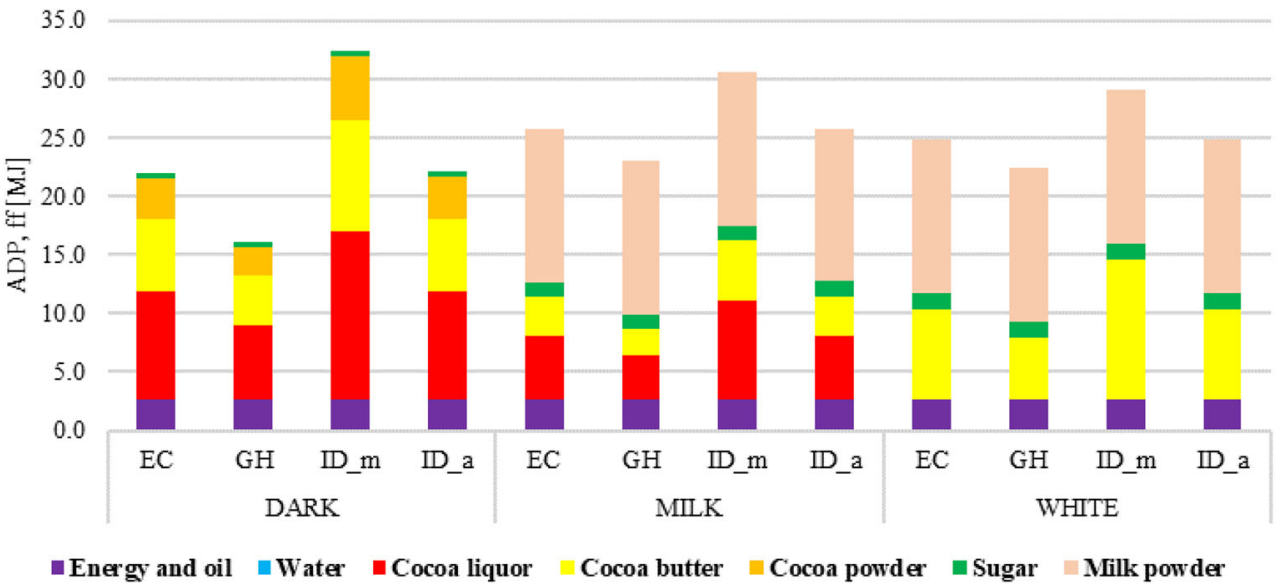


Fig. 9 Water use impacts of $1 \mathrm{~kg}$ dark, milk and white chocolate according to mass allocation (Ecuador EC, Indonesia monoculture system IDm, Indonesia agroforestry system IDa)

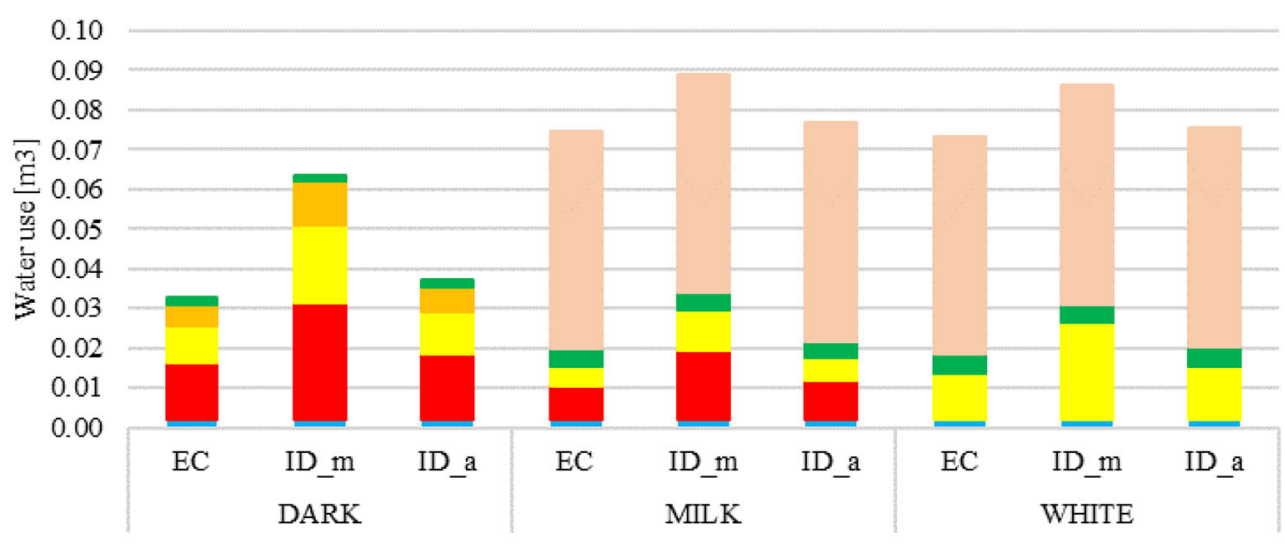

Energy and oil $\square$ Water $\square$ Cocoa liquor $\quad$ Cocoa butter $\square$ Cocoa powder $\square$ Sugar $\square$ Milk powder el, whereas fertilizer production contributes between $40.2 \%$ (Ghana) and 62.3\% (Indonesia monoculture system) to ADP, ff.

\subsection{Chocolate manufacturing}

The environmental impacts caused by the production of $1 \mathrm{~kg}$ of chocolate are assessed and compared for dark, milk and white cases. The study evaluates the effects due to the production of ingredients (milk powder, sugar, cocoa liquor, powder and butter), energy and water consumption for final product refining. As in previous literature LCA studies (Konstantas et al. 2018; Vesce et al. 2016), Figs. 3, 4, 5, 6, 7, 8, 9 and 10 show that cocoa derivatives and milk powder provide the major contributions. The first ones are widely influenced by the producer countries. Indeed farming requests an intensive use of agrochemicals and the bean transforming phase needs a high energetic consumption (Ntiamoah and Afrane 2008). The milk powder manufacturing also has an intensive energetic usage because of evaporation and drying steps (Finnegan et al. 2017). For instance, in Ecuador case study, AP impacts are mainly due to cocoa derivatives (96\%) in dark chocolate, cocoa derivatives (19\%) and milk powder (63\%) in milk chocolate and cocoa butter (27.6\%) and milk powder (65.1\%) in white chocolate. Similar percentages are obtained for EP: analyzing Ghana as farmer country cocoa derivatives contributes for $91 \%$ in dark chocolate, while $76.3 \%$ is due to milk powder in white one. In accordance with literature (Büsser and Jungbluth 2009), the milk and white chocolates have the most relevant GWP impact: considering an average value between proposed situations, about $4 \mathrm{~kg} \mathrm{CO} 2$ eq. are obtained in comparison with $2 \mathrm{~kg}$ $\mathrm{CO}_{2}$ eq. due to dark chocolate production. POCP and ADP, ff have quite similar results, as the milk powder present in milk and white chocolate compensates for the major amount of cocoa co-products in dark chocolate. On the contrary, ADP, el impacts result higher for dark chocolate since the contribution (per mass unit) of milk powder is lower, due to the relevant impact of pesticides applied during cocoa cultivation. Except for Ghana case study where a considerable amount of water is used by cocoa farming, the milk powder production requests about $70 \%$ of net water consumption in chocolate supply chain (Fig. 9), whereas the water use for property chocolate refining step is very low (Vesce et al. 2016). Similar considerations are valid for needed energy: indeed, only the milk powder manufacturing spends $46 \mathrm{MJ}$ (around 66\%) as Fig. 10 shows.
Fig. 10 CED impacts of $1 \mathrm{~kg}$ dark, milk and white chocolate according to mass allocation (Ecuador EC, Ghana GH, Indonesia monoculture system IDm, Indonesia agroforestry system IDa)

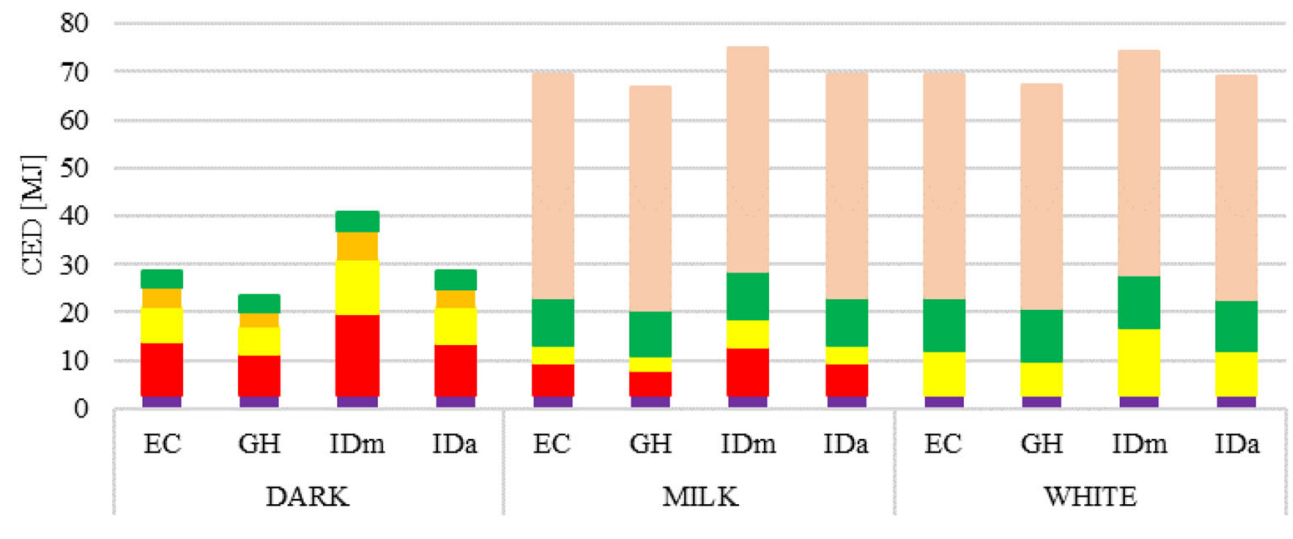

$\square$ Energy and oil $\square$ Water $\square$ Cocoa liquor Cocoa butter $\square$ Cocoa powder $\square$ Sugar $\square$ Milk powder 


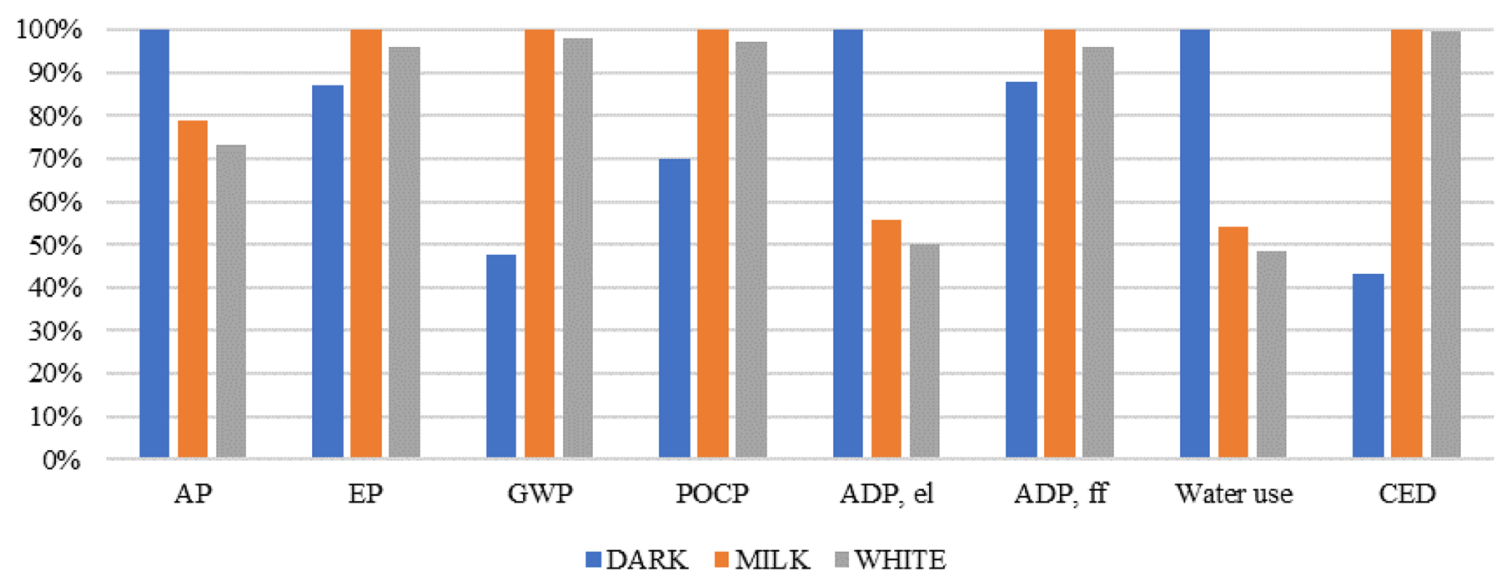

Fig. 11 Comparison of potential environmental impacts of $1 \mathrm{~kg}$ of dark, milk and white chocolate (average values among different producer countries)

In general, as reported in Fig. 11, dark chocolate shows a better performance in the categories where impacts deriving from milk powder production are predominant (i.e. EP, GWP, POCP ADP, ff, CED), whereas it overtakes milk and white chocolate as milk powder contribution decreases. Water use represents a separate case since the comparison is strongly influenced by the water consumption for cocoa cultivation in Ghana (Fig. 2). Moreover, milk and white chocolate present similar results since they contain the same amount of milk powder and similar amounts of cocoa co-products (Table 1). Therefore, even though the comparison among different chocolate types varies according to the considered environmental impact category, still dark chocolate globally shows the best environmental performance, followed by white chocolate and then milk chocolate.

\subsection{Packaging production and end-of-life treatments}

In chocolate supply chain, the main causes of pollution are the used raw materials: above all dairy and cocoa derivatives. Certainly, the careful choice of products with lower environmental impacts, resulting from a better management of their cultivation and processing, could improve system performances. An alternative is the substitution of some ingredients; for instance, the use of soy milk, instead of cow milk, could reduce the impacts up to 70-90\% (Miah et al. 2018). However, this solution is not always possible because the replacement changes the characteristics of the final product, such as taste, nutrition values and physical appearance. For this reason, an easier reduction of impacts can be obtained focusing on packaging materials. Figure 12 presents the environmental impacts generated by the packaging production to wrap $1 \mathrm{~kg}$ of chocolate. The polypropylene (PP) layer results to be the least impacting material in all chosen impact categories. Two different combinations of an aluminium foil with a fibre-based material result more impacting than the PP case, mainly because of aluminium-based material production. Consequently, the aluminium layer plus cardboard is the most impacting solution in all categories: respectively, $0.0021 \mathrm{~kg}$ $\mathrm{SO}_{2}$ eq. for $\mathrm{AP}, 0.0008 \mathrm{~kg} \mathrm{PO}_{4}{ }^{3-}$ eq. for $\mathrm{EP}, 0.4228 \mathrm{~kg} \mathrm{CO}_{2}$ eq. for GWP, $0.0012 \mathrm{~kg} \mathrm{NMVOC} \mathrm{eq.} \mathrm{for} \mathrm{POCP,} 1.7010^{-6} \mathrm{~kg}$ $\mathrm{Sb}$ eq. for ADP, el, $4.1419 \mathrm{MJ}$ for $\mathrm{ADP}, \mathrm{ff}, 0.0035 \mathrm{~m}^{3}$ for water use and $5.7136 \mathrm{MJ}$ for energy consumption.

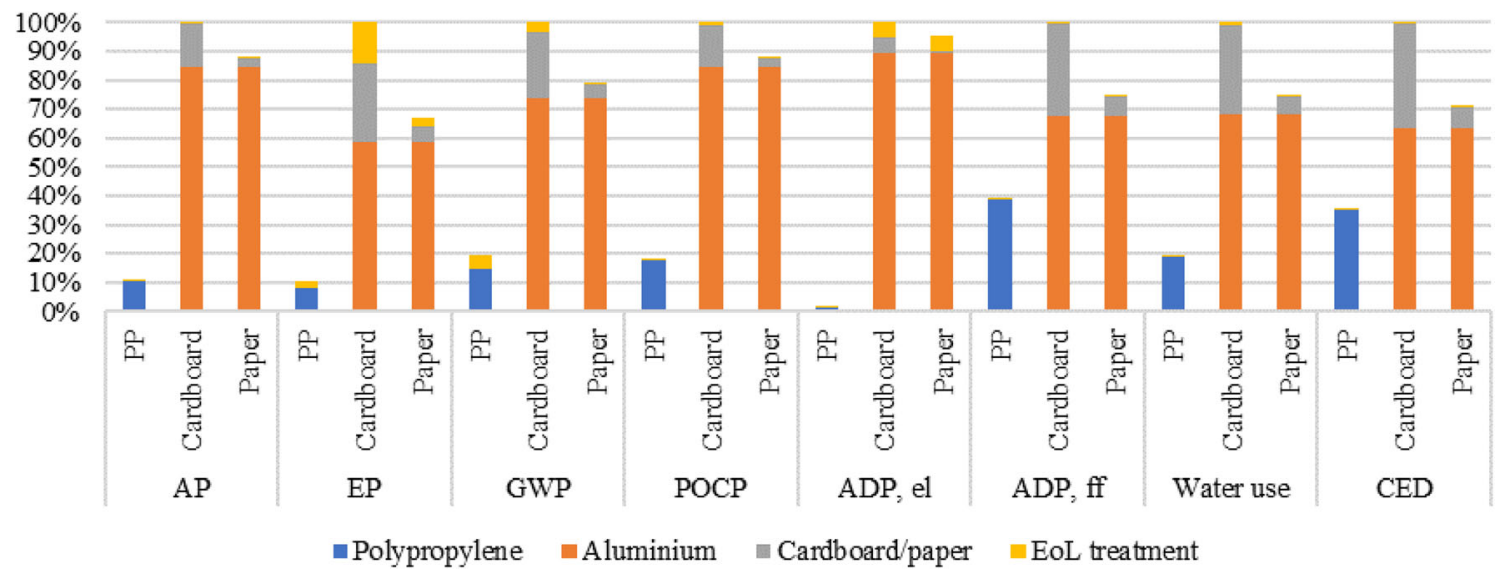

Fig. 12 Environmental impacts due to production of packaging materials to wrap $1 \mathrm{~kg}$ chocolate 
Table 9 Comparison between mass allocation and energy content allocation

\begin{tabular}{lllll}
\hline Cocoa co-product & Mass $[\mathrm{g}]$ & Mass allocation & Total energy content $[\mathrm{kcal}]$ & Energy content allocation \\
\hline Cocoa liquor & 98 & $21.3 \%$ & 635.3 & $19.8 \%$ \\
Cocoa butter & 202 & $43.9 \%$ & $1,816.1$ & $56.7 \%$ \\
Cocoa powder & 160 & $34.8 \%$ & 751.4 & $34.8 \%$ \\
\hline
\end{tabular}

\subsection{Sensitivity analysis}

Mass allocation is usually suggested when allocation procedures cannot be avoided and no different physical relationships reflect the way in which the inputs and outputs are changed by quantitative variations in the products delivered by the system (IES 2019). Thus, mass allocation is applied in the first point to the cocoa co-products as defined in paragraph 2.2.2. Since different allocation choices could strongly affect the results and owing to the common use of chocolate as energy food, allocation rules based on the cocoa co-product energy content are proposed for the sensitivity analysis. The caloric intakes for cocoa liquor, cocoa butter and cocoa powder are respectively equal to $648.3 \mathrm{kcal} / 100 \mathrm{~g}, 899.05 \mathrm{kcal} /$ $100 \mathrm{~g}$ and $469.6 \mathrm{kcal} / 100 \mathrm{~g}$ (MP\&F 2020). As reported in Table 9, this allocation choice leads to a higher allocation percentage for cocoa butter $(56.7 \%$ instead of $43.9 \%)$ and to lower allocation percentages for cocoa liquor and cocoa powder (respectively $19.8 \%$ and $23.5 \%$ instead of $21.3 \%$ and $34.8 \%$ ), proportionally affecting their environmental impacts. As shown in Figs. 13 and 14 for GWP category, the energy content allocation slightly rises the environmental impacts of both milk and white chocolate because of the increased impacts of cocoa butter. On the contrary, dark chocolate shows almost equal impacts as the presence of all three cocoa coproducts balances the result variation. The change linked to cocoa butter also leads white chocolate to become more impacting than milk chocolate, since cocoa butter-the only cocoa co-product contained in white chocolate-is strongly unfavoured by the energy content allocation. Except for different percentage changes, the same behaviour occurs for all considered impact categories and indicators as shown by the results presented in the Supplementary Material.

Possible variation in the results could also be caused by different proportions among the mass of cocoa co-products obtained in chocolate manufacturing, as cocoa liquor contains both cocoa powder and cocoa butter in roughly equal proportion. Therefore, according to the existing proportion between cocoa butter and powder and maintaining the same overall mass for cocoa co-products (Table 6), different percentage variations in the output of cocoa liquor are applied to the manufacturing phase in the case of energy content allocation. However, as shown in Fig. 15 for GWP, the variation of the results is substantially negligible for all chocolate types in the case of energy content allocation, whereas no change is present in the case of mass allocation.

Finally, a comparison between two allocation methods is evaluated considering a functional unit of $1 \mathrm{kcal}$. The conversion of functional unit is computed according to average energy content for three chocolate types (Verna 2013): 4950 $\mathrm{kcal} / \mathrm{kg}$ of dark chocolate, $5150 \mathrm{kcal} / \mathrm{kg}$ of milk chocolate and $5400 \mathrm{kcal} / \mathrm{kg}$ for white chocolate. Thus, looking at chocolate for its primary function of energy food, the application of an energy-based functional unit turns back to favour-in

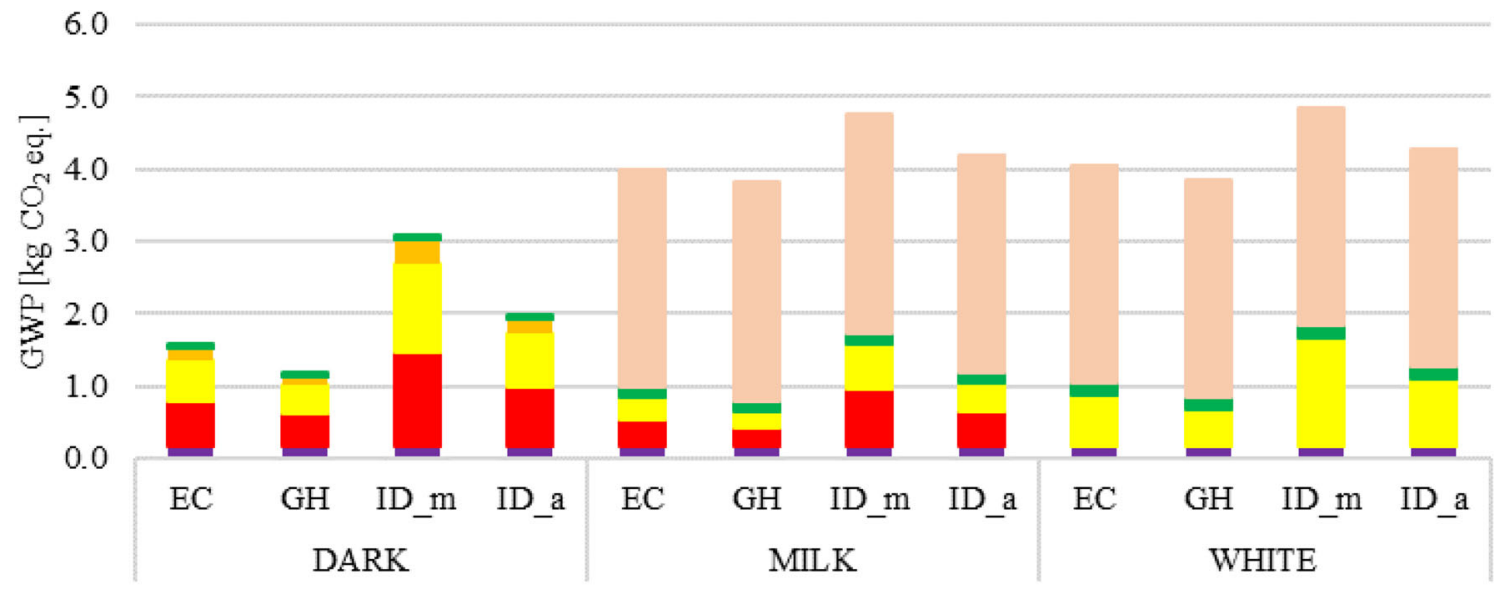

$\square$ Energy and oil $\square$ Water $\square$ Cocoa liquor Cocoa butter $\backsim$ Cocoa powder $\square$ Sugar Milk powder

Fig. 13 GWP impacts of $1 \mathrm{~kg}$ dark, milk and white chocolate according to energy content allocation (Ecuador EC, Ghana GH, Indonesia monoculture system IDm, Indonesia agroforestry system IDa) 


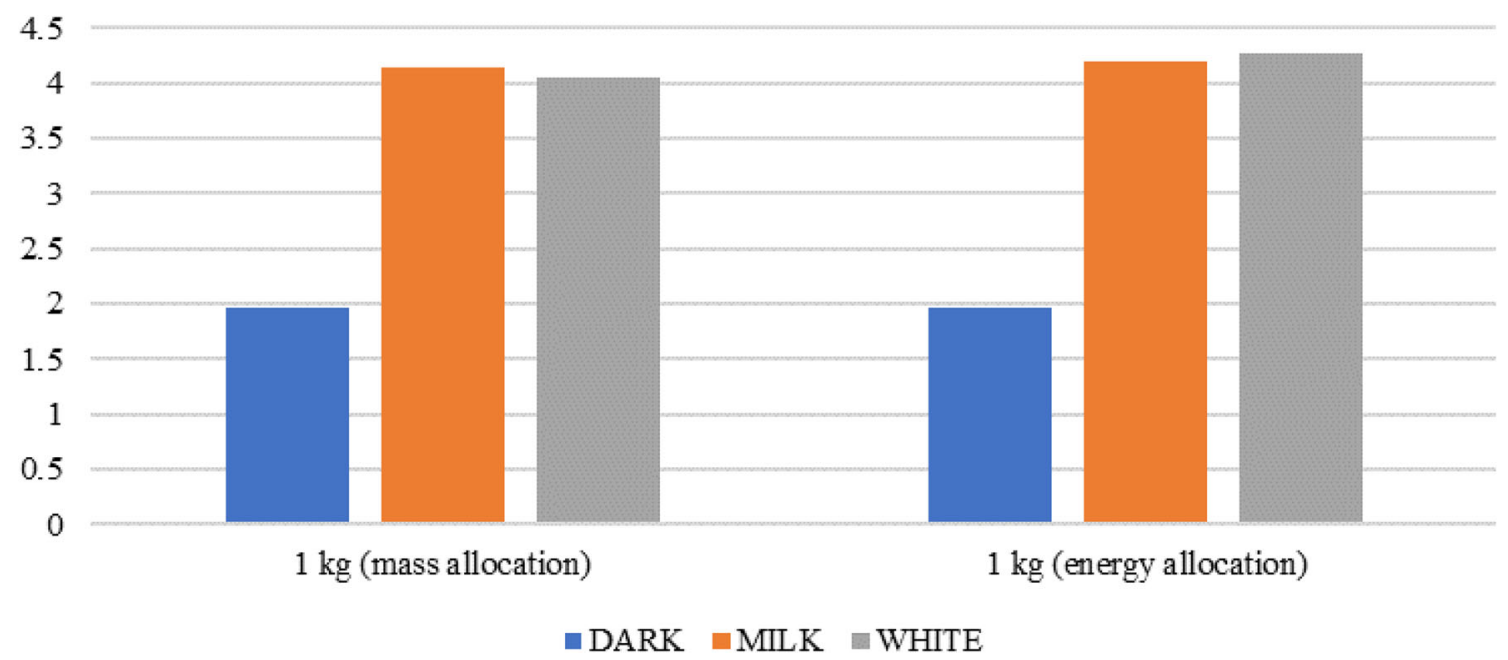

Fig. 14 GWP impacts of $1 \mathrm{~kg}$ of dark, milk and white chocolate (average values among different producer countries)

terms of GWP — white chocolate instead of milk chocolate in both the allocation rules applied (Fig. 16), as for the original case of $1 \mathrm{~kg}$ of product with mass allocation (Fig. 14).

However, regardless of the functional unit and the allocation rules applied, the qualitative comparison among three chocolate types remains similar.

\section{Conclusion}

The environmental impact analysis of the food supply chain is becoming a relevant topic due to its considerable consequences and, at the same time, higher attention of consumers to more sustainable product choice. In this context and owing to the continuous increase of cocoa demand, the comparison among dark, milk and white chocolate life cycle is proposed through LCA methodology from cradle to grave. Several possible situations are analyzed, considering different cocoa producer countries. Indeed, each zone and farming technique (monoculture or agroforestry system) has specific environmental impacts depending on requested inputs. The analysis shows that Ghana case study has minor consequences, due to lower use of fertilizers and pesticides and travelled distance between cocoa fields and factory; yet a higher water value is consumed. The raw material production, specifically cocoa co-products and milk powder, has the major influence in all considered categories. In addition, packaging material comparison is proposed analyzing different possible choices. The best solution is a single PP layer, whereas the commonly used aluminium foil with an external fibre-based pack has higher environmental impacts. According to the performed sensitivity analysis, the comparison between two applied allocation procedures - mass and energy content - does not show a remarkable difference, highlighting their equal validity in the
Fig. 15 Sensitivity analysis for chocolate manufacturing - GWP

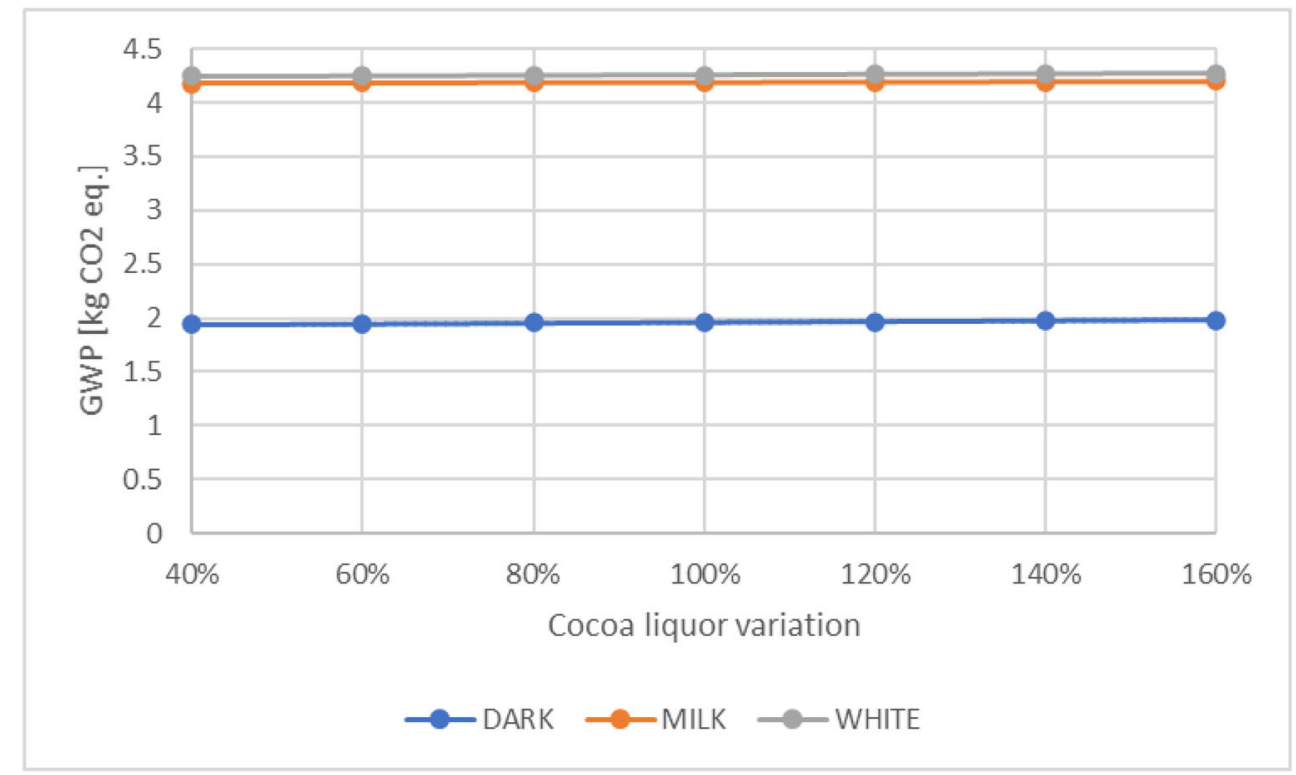




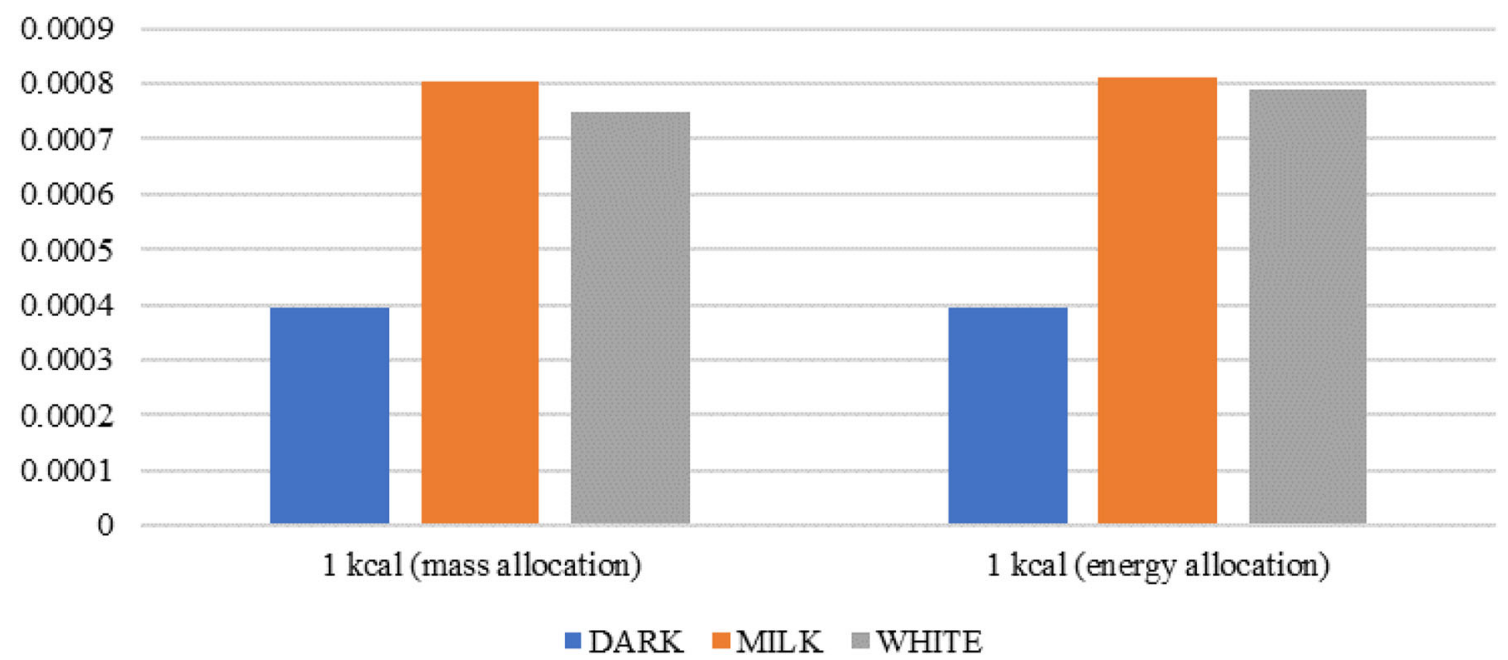

Fig. 16 GWP impacts of $1 \mathrm{kcal}$ of dark, milk and white chocolate (average values among different producer countries)

application to chocolate LCA studies. In both cases, dark chocolate globally presents the best environmental performance, whereas the other two types have similar environmental impacts. These results are also qualitatively confirmed in the case of calories as functional units.

Acknowledgements Open access funding provided by Università degli Studi di Genova within the CRUI-CARE Agreement.

Open Access This article is licensed under a Creative Commons Attribution 4.0 International License, which permits use, sharing, adaptation, distribution and reproduction in any medium or format, as long as you give appropriate credit to the original author(s) and the source, provide a link to the Creative Commons licence, and indicate if changes were made. The images or other third party material in this article are included in the article's Creative Commons licence, unless indicated otherwise in a credit line to the material. If material is not included in the article's Creative Commons licence and your intended use is not permitted by statutory regulation or exceeds the permitted use, you will need to obtain permission directly from the copyright holder. To view a copy of this licence, visit http://creativecommons.org/licenses/by/4.0/.

\section{References}

ADICONSUM (2003) L'etichetta del cacao e del cioccolato. http://www. adiconsum.it/files/guide_tematiche/Etichetta $\% 20$ cacao $\% 20 \mathrm{e} \%$ 20cioccolato.pdf. Accessed 3 January 2020

Allione C, De Giorgi C, Lerma B, Petruccelli LA (2011) Sustainable food packaging: a case study of chocolate products. https://www. semanticscholar.org/paper/Sustainable-food-packaging\%3A-acase-study-of-Allione-Giorgi/3c17dcdb2bff44a95b5541b0 cafa556cb12a7de7. Accessed 9 February 2020

Barona E, Ramankutty N, Hyman G, Coomes OT (2010) The role of pasture and soybean in deforestation of the Brazilian Amazon. Environ Res Lett 5:024002. https://doi.org/10.1088/1748-9326/5/ 2/024002

Bouwman AF, Boumans LJM, Batjes NH (2002) Modeling global annual $\mathrm{N}_{2} \mathrm{O}$ and $\mathrm{NO}$ emissions from fertilized fields. Glob Biogeochem Cycles 16(4):28-1-28-9. https://doi.org/10.1029/2001GB001812
Büsser S, Jungbluth N (2009) LCA of chocolate packed in aluminium foil based packaging. ESU-services Ltd. https://www.esu-services.ch. Accessed 15 September 2019

Canellada F, Laca A, Laca A, Díaz M (2018) Environmental impact of cheese production: a case study of a small-scale factory in southern Europe and global overview of carbon footprint. Sci Total Environ 635:167-177. https://doi.org/10.1016/j.scitotenv.2018.04.045

CBI Ministry of Foreign Affairs (2019) What is the demand for cocoa on the European market? https://www.cbi.eu/market-information/ cocoa/trade-statistics/. Accessed 13 May 2020

Chapa J, Farkas B, Bailey RL, Huang JY (2020) Evaluation of environmental performance of dietary patterns in the United State considering food nutrition and satiety. Sci Total Environ 722:137672. https://doi.org/10.1016/j.scitotenv.2020.137672

CIAL (2019) Riciclo imballaggi alluminio: risultati 2018. https://www. cial.it/risultati-riciclo-alluminio-2018/. Accessed 29 April 2020

COMIECO (2019) $24^{\circ}$ Rapporto "Raccolta, Riciclo e Recupero di carta e cartone". https://www.comieco.org/downloads/12721/7911/24morapporto-comieco_dati-anno-2018.pdf. Accessed 29 April 2020

Cooper K, Donovan J, Waterhouse A, Williamson G (2008) Cocoa and health: a decade of research. Br J Nutr 99(1):1-11. https://doi.org/ 10.1017/S0007114507795296

COREPLA (2019) Rapporto di sostenibilità 2018. http://www.corepla.it/ documenti/7ebe111b-2082-46d5-8da6-7567154632ca/Rapporto+ di+Sostenibilita\%CC\%80+2018.pdf. Accessed 29 April 2020

Del Borghi A, Gallo M, Strazza C, Del Borghi M (2014) An evaluation of environmental sustainability in the food industry through Life Cycle Assessment: the case study of tomato products supply chain. J Clean Prod 78:121-130. https://doi.org/10.1016/j.jclepro.2014.04.083

Del Borghi A, Strazza C, Magrassi F, Taramasso AC, Gallo M (2018) Life Cycle Assessment for eco-design of product-package systems in the food industry-the case of legumes. Sustain Prod Consum 13: 24-36. https://doi.org/10.1016/j.spc.2017.11.001

Del Borghi A, Moreschi L, Gallo M (2020) Circular economy approach to reduce water-energy-food nexus. Curr Opin Environ Sci Health 13:23-28. https://doi.org/10.1016/j.coesh.2019.10.002

EMEP/CORINAIR (2002) Emission Inventory Guidebook - 3rd edition October 2002

FAO (2017) FAOSTAT. http://www.fao.org/faostat.Accessed 30 January 2019

Finnegan W, Goggins J, Clifford E, Zhan X (2017) Environmental impacts of milk powder and butter manufactured in the Republic of 
Ireland. Sci Total Environ 579:159-168. https://doi.org/10.1016/j. scitotenv.2016.10.237

García-Herrero L, DeMenna F, Vittuari M (2019) Sustainability concerns and practices in the chocolate life cycle: integrating consumers' perceptions and experts' knowledge. Sustain Prod Consum 20: 117-127. https://doi.org/10.1016/j.spc.2019.06.003

Gebreselassie H, Atinafu G, Degefa M, Ayano A (2017) Growth characteristics and yield evaluation of Arabica coffee (Coffea arabica L.) promising selections under Sidama and Gedeo growing condition, Southern Ethiopia. Adv Crop Sci Technol 5:6. https://doi.org/10. 4172/2329-8863.1000317

Goedkoop MJ, Heijungs R, Huijbregts M, De Schryver A, Struijs J, Van Zelm R (2009) ReCiPe 2008. A life cycle impact assessment method which comprises harmonised category indicators at the midpoint and the endpoint level; First edition Report I: characterization, first edition, 6 January 2009. http://www.lcia-recipe.net/. Accessed 29 April 2020

Hospido A, Vazquez ME, Cuevas A, Feijoo G, Moreira MT (2006) Environmental assessment of canned tuna manufacture with a lifecycle perspective. Resour Conserv Recycl 47:56-72. https://doi.org/ 10.1016/j.resconrec.2005.10.003

ICCO (2020) International Cocoa Organization. https://www.icco.org/. Accessed 29 April 2020

IES (2019) Grain mill products, starches and starch products; other food products. Product category classification: UN CPC 23. https://www. environdec.com/PCR/Detail/?Pcr=5832. Accessed 13 May 2020

Ingrao C, Matarazzo A, Tricase C, Clasadonte MT, Huisingh D (2015) Life Cycle Assessment for highlighting environmental hotspots in Sicilian peach production systems. J Clean Prod 92:109-120. https://doi.org/10.1016/j.jclepro.2014.12.053

Ingrao C, Licciardello F, Pecorino B, Muratore G, Zerbo A, Messineo A (2018) Energy and environmental assessment of a traditional durum-wheat bread. J Clean Prod 171:1494-1509. https://doi.org/ 10.1016/j.jclepro.2017.09.283

IPCC (2006) Guidelines for national greenhouse gas inventories

ISO (2006a) ISO 14025:2006: Environmental Labels and Declarations type III environmental claims. https://www.iso.org/standard/38131. $\mathrm{html}$. Accessed 5 January 2020

ISO (2006b) ISO 14040:2006: Environmental Management - Life Cycle Assessment - principles and framework. https://www.iso.org/ standard/37456.html. Accessed 5 January 2020

ISO (2006c) ISO 14044:2006: Environmental Management - Life Cycle Assessment - principles and framework. https://www.iso.org/ standard/38498.html. Accessed 5 January 2020

Kamp A, Østergård H (2016) Environmental sustainability assessment of fruit cultivation and processing using fruit and cocoa residues for bioenergy and compost. Case study in Ghana. J Clean Prod 129: 329-340. https://doi.org/10.1016/j.jclepro.2016.04.065

Konstantas A, Jeswani HK, Stamford L, Azapagic A (2018) Environmental impacts of chocolate production and consumption in the UK. Int Food Res J 106:1012-1025. https://doi.org/10.1016/ j.foodres.2018.02.042

López-Andrés JJ, Aguilar-Lasserre AA, Morales-Mendoza LF, AzzaroPantel C, Pérez-Gallardo JR, Rico-Contreras JO (2018) Environmental impact assessment of chicken meat production via an integrated methodology based on LCA, simulation and genetic algorithms. J Clean Prod 174:477-491. https://doi.org/10.1016/j. jclepro.2017.10.307

McAuliffe GA, Takahashi T, Lee MRF (2020) Applications of nutritional functional units in commodity-level life cycle assessment (LCA) of agri-food systems. Int J Life Cycle Assess 25:208-221. https://doi. org/10.1007/s11367-019-01679-7

Miah JH, Griffiths A, McNeill R, Halvorson S, Schenker U, EspinozaOrias ND, Morse S, Yang A, Sadhukhan J (2018) Environmental management of confectionery products: life cycle impacts and improvement strategies. J Clean Prod 177:732-751. https://doi. org/10.1016/j.jclepro.2017.12.073

MP\&F (2020) https://mpf.com/. Accessed 29 April 2020

Nayak PK, Patel MK, Panda CM, Swain S (2019) Yield performance of commercial banana cultivars propagated through different methods. J Pharm Innov 8(10):61-63

Nemecek T, Jungbluth N, Canals LM, Schenck R (2016) Environmental impacts of food consumption and nutrition: where are we and what is it the next? Int J Life Cycle Assess 21:607-620. https://doi.org/10. 1007/s11367-016-1071-3

Ntiamoah A, Afrane G (2008) Environmental impacts of cocoa production and processing in Ghana: life cycle assessment approach. J Clean Prod 16:1735-1740. https://doi.org/10.1016/j.jclepro.2007. 11.004

Ortiz OO, Gallardo RAV, Rangel JM (2014) Applying life cycle management of Colombian cocoa production. Food Sci Technol 34(1): 62-68 http://www.scielo.br/scielo.php?script=sci_arttext\&pid= S0101-20612014000100009\&lng=en\&nrm=iso

Pérez Neira D (2016) Energy sustainability of Ecuadorian cacao export and its contribution to climate change. A case study through product life cycle assessment. J Clean Prod 112:2560-2568. https://doi.org/ 10.1016/j.jclepro.2015.11.003

Persistence Market Research (2018) Global market study on white chocolate: growing demand in food \& beverage and cosmetics industry to fuel growth during 2017-2026. https://www. persistencemarketresearch.com/market-research/white-chocolatemarket.asp. Accessed 13 May 2020

Recanati F, Marveggio D, Dotelli G (2018) From beans to bar: a life cycle assessment towards sustainable chocolate supply chain. Sci Total Environ 613-614:1013-1023. https://doi.org/10.1016/j.scitotenv. 2017.09.187

Reverberi A, Del Borghi A, Dovì V (2011) Optimal design of cogeneration systems in industrial plants combined with district heating/ cooling and underground thermal energy storage. Energies 4(12): 2151-2165. https://doi.org/10.3390/en4122151

Roy P, Nei D, Orikasa T, Xu Q, Okadome H (2009) A review of life cycle assessment (LCA) on some food product. J Food End 90:1-10. https://doi.org/10.1016/j.jfoodeng.2008.06.016

Scheepens AE, Vogtländer JG (2016) Brezet J C (2016) Two life cycle assessment (LCA) based methods to analyse and design complex (regional) circular economy systems. Case: making water tourism more sustainable. J Clean Prod 114:257-268, ISSN 0959-6526. https://doi.org/10.1016/j.jclepro.2015.05.075

Solazzo R, Donati M, Tomasi L, Arfini F (2016) How effective is greening policy in reducing GHG emissions from agriculture? Evidence from Italy. Sci Total Environ 573:1115-1124. https://doi.org/10. 1016/j.scitotenv.2016.08.066

Sonesson U, DavisJ FA, Gustavsson J, Witthöft C (2017) Protein quality as functional unit - a methodological framework for inclusion in life cycle assessment of food. J Clean Prod 140:470-478. https://doi. org/10.1016/j.jclepro.2016.06.115

Strazza C, Del Borghi A, Magrassi F, Gallo M (2016) Using environmental product declaration as source of data for life cycle assessment: a case study. J Clean Prod 112:333-342. https://doi.org/10. 1016/j.jclepro.2015.07.058

Torres-Moreno M, Tarrega A, Costell E, Blanch C (2012) Dark chocolate acceptability: influence of cocoa origin and processing conditions. $\mathrm{J}$ Sci Food Agric 92:404-411. https://doi.org/10.1002/jsfa.4592

Transparency Market Research (2018) Milk chocolate market report. https://www.transparencymarketresearch.com/milk-chocolatemarket.html. Accessed 13 May 2020

Tricase C, Lamonaca E, Ingrao C, Bacenetti J, Lo Giudice A (2018) A comparative Life Cycle Assessment between organic and conventional barley cultivation for sustainable agriculture pathway. J Clean Prod 172:3747-3759. https://doi.org/10.1016/j.jclepro.2017.07.008 
University of Leiden (2016) CML 2001 - January 2016 methodology. https://www.universiteitleiden.nl/en/research/research-output/ science/cml-ia-characterisation-factors\#downloads. Accessed 29 April 2020

Utomo B, Prawoto AA, Bonnet S, Bangviwat A, Gheewala SH (2016) Environmental performance of cocoa production from monoculture and agroforestry systems in Indonesia. J Clean Prod 134:583-591. https://doi.org/10.1016/j.jclepro.2015.08.102

Verna R (2013) The history and science of chocolate. Malays J Pathol 35(2):111-121

Vesce E, Olivieri G, Pairotti MB, Romani A, Beltramo R (2016) Life cycle assessment as a tool to integrate environmental indicators in food products: a chocolate LCA case study. Int J Environ Health 8(1):21-37. https://doi.org/10.1504/IJENVH.2016.077660

Wernet G, Bauer C, Steubing B, Reinhard J, Moreno-Ruiz E, Weidema B (2016) The ecoinvent database version 3 (part I): overview and methodology. Int J Life Cycle Assess 21:1218-1230. https://doi. org/10.1007/s11367-016-1087-8

Publisher's note Springer Nature remains neutral with regard to jurisdictional claims in published maps and institutional affiliations. 